\title{
Participation of youth in socio-political processes in the process of globalization
}

\author{
Saidova Sayyora Alisher qizi, PhD \\ E-mail: Sayyora.Saidova@mail.ru
}

\begin{abstract}
This article describes the process of globalization, its types and the analysis of the importance of youth education in this process. In addressing the global problems of young people, above all the knowledge and skills to serve as the basis of their educational process were found to be the main tool. In addition, analysis of the practical work carried out in this direction.
\end{abstract}

Key words: globalization, youth, education, demography, national and universal values, religion, society and the modern.

\section{Introduction}

In recent years, based on a variety of views on globalization, almost all of the social events associated with the interpretation of one of the problems. Nevertheless, the nature of the complex and multifaceted nature of this phenomenon, it is not formed a holistic scientific approach and perspective.

First of all, when it comes to this issue, it should be noted: "Globalization is coming fast and deep lives spoke about the main factor and the reason I have to admit that the objective of any state of development and prosperity not only in the near and distant neighbors, but inseparably connected with other regions and territories across the world come to any country in this process, such positive results - does not understand and is not that difficult ".

Research has given special attention to the political aspects of globalization rather than one or the other economic aspects can be emphasized in demographic processes .

In addition, they are the result of the improvement in information technology, globalization, and unprecedented approach to priorities. Of course, each of these approaches in its remarks on the rational. As well as the effects caused by globalization experts, is estimated to be as positive and negative process.

M.Delyagin claims globalization as the basis of advanced computer technologies are integral and global scales, even if at the same time, the limits of military, political, financial and economic information space and as a process of formation .

L.E.Grinin writes about globalization: "the result of the convergence of globalization and integration of the region and the world as a whole. Globalization is a process, and the world as a result of his own subjects more relevant and more ".

\section{Main part}

In addition, "according to the mean of globalization of the universal common understanding of issues. This understanding is one-sided and does not reveal the essence of his only be interpreted as a negative phenomenon of globalization. In fact, the most general sense, globalization, on the one hand, in certain cases, to all parts of the process, the countries agreed to cover the whole face of the earth and on the other hand, means that the destiny of humanity ".

At the same time, some of the experts in the process of global development based on the analysis of trends in most cases axiomatic some conclusions noting the need for a critical approach to be adopted . In particular, the conditions of globalization, the world's largest companies from the benefits of growth, towards recession, governments, yet still retain the possibility to influence the activities of the giant corporations and, in many cases, forced them to change their plans and looking at writing.This is another group of experts opinions on the importance of state borders by the sharp fall the way indicative of the one-sided nature.

Opinions about the fact that to the negative features of globalization as a whole. After all, which is also reflected in certain aspects of the phenomenon.

Analysis of particular regions and political problems which emerged in the region in a short time lead to the emergence of other types of difficulties in the political sphere that the main feature of globalization. As well as experts in this regard political institutions and processes in the growth of global interdependence, in turn, leads to global political weakness of the sanctuary, and an unstable political situation at the inevitable negative impact on political life in other parts of the world about the conclusion .

At the same time, according to experts, a number of technical development as a consequence of globalization represents a new stage in the development of civilization. At the same time, they have the intellectual resources in the context of globalization and the globalization of high-tech leaders for the accumulation of a number of countries within the framework of its relatively closed nature of the particular emphasis given to the country. The global assessment of the conditions of young people can be protected from any major problem.

Islam Karimov, declared: "The protection of the hearts and minds of the younger generation in the spirit of national and universal values, the essence of the 
political processes taking place in the world of our children and the deep understanding of the real causes of their truth about the events taking place around the data, and most importantly, they should have their own independent view, simple, intricate unable to achieve educational and spiritual work should have the basic conditions and criteria. Allocation of values in society leads to the emergence of various problems. Leads to the occurrence of the problems of the size and global threats. This was later increased threats to the life of society, especially young people. An increase in threats to the lives of young people in ideology can lead to the collapse of the country".

However development of a technological society, it is a historical period of human spiritual and educational development of young people, training on new, complex issues. This problem becomes more serious in the process of globalization. Humanity, that this is a problem in all societies, thinkers, philosopher, political scientists, educators and coaches has been the center of attention. On the plaque of one of the Pharaohs who lived about three and a half thousand years ago was written: "The youth is stubborn and obstinate, and they ignore the words of elderly people and deny the values of our ancestors," the inscription, is also the youth at all levels of education and human development to become one of the main issues up.

As you know, the education and culture of any society, is an important factor in the development of the state. Did not pay attention to the educational affairs of society, the nation, and ultimately keep the impoverishment of the spiritual life of the family were proven true.

Ideological view of the world has changed, man has become the main issue in the struggle for the hearts and minds of a healthy, creative ideas are important. Not to create vacuum in the spiritual world of the young people in their hearts and minds healthy way of life, a sense of national and religious values, respect for the early formation of the moment.

Now upbringing of high moral standing, special attention is paid to ensuring the rule. "Public Opinion", according to the survey conducted by the Public Opinion Research Center, 73.1 percent of citizens in shaping a person forming universal values high moral qualities are important, as well. This is, above all, kindness, compassion, respect for elders, hospitality, generosity, friendship, honesty, humility, diligence, concepts .

It should be noted that moral hadithes play an important role on the formation of these qualities in the minds of the young generation. After all, the qualities of this concept lies in the basis of national values, national values, which in turn is closely linked to religious values.

The first family, discipline, is why education is important. Its impact on human nature. Personality psychology, behavior and habits formed in childhood ore. Thus, the vanities of human perfection, or go back to his family discipline. Family environment improves the strength and the moral and spiritual environment, the development of the individual person and of society as well as the primary factor in determining the future.

Children to be the best team not to make a mistake in this regard, public opinion plays an important role in the deliberative opinion of the majority. So, public opinion in the person of life, the fate of an invaluable role in defining priorities. In this context, the Western laws, customs and traditions of the East managed, refers to recall it. In fact, in the east, including Uzbeks, living as many of the high level of customs laws. In particular, the family or a public ceremony held in the middle of the neighborhood, in fact, many neighbors traditions of family life performed at the level of customs legislation .

Formed over the centuries, our national values, customs and traditions of our immense wealth, independence guarantee a solid foundation and bright future. Today's era of globalization, the human mind and sharpen the struggle to occupy the thinking of young people, foreign ideas and ideology, the negative impact of attempts to draw more power conditions, the ancestors, the dreams, the hopes, aspirations and reflects the thinking of the priceless wealth of carefully preserve the rich and the generation of young people consciousness congruently task more urgent .

\section{Conclusion}

As a solution to the issues listed above, the process of education and training to foster a spirit of universal respect for national and religious values to bring them to the need to give special attention to the formation of concepts. For this purpose, the essence of the spiritual perfection of the human factors analysis, along with their humanity, reveals the essence of the ideas of spiritual maturity will be well-timed. Given the spiritual essence of the quintessential globalized ideological attacks, carried out in violation of national and religious values among the youth refused to blindly mimic the mood shows the growing importance of living in peace and tranquility. Therefore, the education of the young generation of our society, the perfect human vision plays an important role.

\section{References}

1.А.А.Маврулов. Маънавий баркамол инсон тарбияси. - Т.: “Ўзбекистон”, 2008. - Б.5.

2.Афдурауф Фитрат. Оила.-Т.: Маънавият нашриёти, 2000. - Б. 34.

3.Ashirov A. On the concept of Uzbek Etnic mentality// Central Asian Studies Vol.8. Seoul 2003. P. 261-267.

4.Бу мақаддас Ватанда азиздир инсон. -Т.: Ғофур Ғулом номидаги нашриёт-матбаа ижодий уйи, 2010. -Б.64. 
5.Каримов И.А. Юксак маънавият - енгилмас куч. - Т.: Маънавият, 2008. - 111 с.

6.Гаджиев К.С. Введение в геополитику. - М.: ЛОГОС, 2000. - 432 с.; Глобализация и моделирование социальной динамики. - М.: Институт социальных наук, 2001. - 237 с.; Крылова И.А. Проблема безопасности России в контексте глобализации. - М: Институт философии РАН, 2001. - 94 с.; Глобализация и моделирование социальной динамики. \Отв. ред. - Николаев В.Р. - М.: Институт социальных наук, 2001. - 212 с.

7.Геогенезис: философия и методология геоэкономики и геофинансов. Научный альманах высоких гуманитарных технологий. \Под. ред. Ивановой Г.М. - М.: НАВИГУТ, 2003. - 250 с.

8.Практическая демография \ Под. ред. Л.Л.Рыбаковского. - М.: ЦСП, 2005. - 164 с.; Рыбаковский Л.Л. Миграция населения. Три стадии миграционного процесса. (Очерки теории и методов исследования). - М.: УФН, 2000. - 164 с.

9.Делягин М. 11 сентября 2001 года: завершение формирования пост-советского мира // Глобализация: варианты для России / Материалы круглого стола - СПб.: Информационное агентство «РосБалт», 2001. - С. 38-49.

10. Гринин Л.Е. Глобализация и национальный суверенитет // История и современность. - Москва, 2005. - № 1, - С. 8-11.

11. Очилдиев А. Глобаллашув ва мафкуравий жараёнлар. - Т.: “Мухаррир нашриёти”, 2009. - Б. 64.

12. Лапкин В.В., Пантин В.И. Геоэкономическая политика и глобальная политическая история. - М.: Изд-во: Олита, 2004. - 280 с.

13. Қаранг: Панарин А. С. Искушение глобализмом. - М.: ЭКСМО-Пресс, 2002. - 416 с.; Москвин Д. Трансформация политической системы России и политические вызовы глобализации // http://mmj.ru/political_science.html.

14. Қаранг: Малашхия Г. Тенденция гуманизации и дегуманизации экономики. В сб. «Отчуждение человека в перспективе глобализации мира». Вып. I / Под ред. Б. Маркова, Ю. Солонина, В. Парцвания. СПб.: Петрополис, 2001. - С. 87-99.; Марков Б. Человек и глобализация мира. В сб. «Отчуждение человека в перспективе глобализации мира». Вып. I / Под ред. Б.Маркова, Ю.Солонина, В.Парцвания. СПб.: Петрополис, 2001. - С. 100-122.; Эко У. Несколько сценариев глобальной войны / Пер. с англ. СПб.: Сайт Философского факультета СПб.ГУ - antropologia.spbu.ru.

15. Бу муқаддас Ватанда азиздир инсон. -Т.: Ғафур Ғулом нрмидаги нашриёт-матбаa ижодий уйи, 2010. - Б. 55.

16. Жамиятни янгилаш ва ислох этиш. -Т.: Ўзбекистон Файласуфлари Миллий жамият нашриёти, 2005. - Б. 18-19.

17. А.А.Маврулов. Маънавий баркамол инсон тарбияси. - Т.: “Ўзбекистон”, 2008. - Б.5.

18. Афдурауф Фитрат. Оила.-Т.: Маънавият нашриёти, 2000. - Б. 34.

19. Ashirov A. On the concept of Uzbek Etnic mentality// Central Asian Studies Vol.8. Seoul 2003. - P. 261-267.

$20 . \quad$ Бу мақаддас Ватанда азиздир инсон. -Т.: Ғофур Ғулом номидаги нашриёт-матбаа ижодий уйи, 2010. -Б.64. 